\title{
Poverty Cycle with Motorcycle Taxis (Boda-Boda) Business in Developing Countries: Evidence from Mbeya-Tanzania
}

\author{
Stewart Mbegu, Joshua Mjema \\ School of Business, Mzumbe University, Mbeya, Tanzania \\ Email:smbegu@mzumbe.ac.tz, stewartmbegu@gmail.com
}

How to cite this paper: Mbegu, S. and Mjema, J. (2019) Poverty Cycle with Motorcycle Taxis (Boda-Boda) Business in Developing Countries: Evidence from Mbeya-Tanzania. Open Access Library Journal, 6: e5617.

https://doi.org/10.4236/oalib.1105617

Received: July 19, 2019

Accepted: August 20, 2019

Published: August 23, 2019

Copyright $\odot 2019$ by author(s) and Open Access Library Inc.

This work is licensed under the Creative Commons Attribution International License (CC BY 4.0).

http://creativecommons.org/licenses/by/4.0/

\begin{abstract}
Motorcycle taxis (Boda-Boda) is a rapidly growing business in most developing countries, particularly sub-Saharan African countries. In recent decades, the statistics of youth employment in Motorcycle taxis (Boda-Boda) is almost doubling every year. Contrary to the reported growth and success of this business, the Motorcycle taxis (Boda-Boda) business has impacted negatively the communities. Reports in most cities and towns in the developing countries indicate that there is a serious increase in accidents involving motorcycle taxis. Urban Insecurity, pollution and traffic is another problem in developing countries' communities associated with Motorcycle taxis (Boda-Boda) business. The findings have identified the negative impacts of Motorcycle taxis (Boda-Boda) business in developing countries' communities relating it to poverty cycle existing in the communities. 200 Boda-Boda riders and 200 Boda-Boda users were purposively chosen to gather primary data, secondary data were collected through internet sources, government reports and other Boda-Boda related materials and documents. SSPS and Excel were used to analyse data. The study has found out that, a Motorcycle taxi (Boda-Boda) user in ten years has more than $90 \%$ chance to sustain injury or lose life. Though users and riders have positive attitude on Motorcycle taxis (Boda-Boda), still more than $80 \%$ of them are aware of the risks associated with them. Primary data with the support of secondary data provide insights that it is difficult to say that the business is contributing to economic growth, instead of poverty cycle from unemployment to pure disabled dependent or from jobless father or mother to orphans' dependents. The government should intervene in Motorcycle taxis (Boda-Boda) business which erodes country's manpower, resources and the economy at large.
\end{abstract}

\section{Subject Areas}

General Business Research 


\section{Keywords}

Poverty Cycle, Motorcycle Taxis, Boda-Boda Business, Developing Countries

\section{Introduction}

The use of Motorcycle taxis (Boda-Boda) as a public transport in most developing countries is growing rapidly; poor public transport in cities and towns is mentioned to be the main reason [1] [2] [3]. Also, high rate of rural-urban migration, high population growth in urban areas, growing of informal sector and poor transport infrastructures in most developing countries contribute to growing rapidly of Boda-Boda as a public transport [3] [4]. The business is attracting small and medium investors in most developing countries; also, youths and politicians count Motorcycle taxis (Boda-Boda) as an alternative employment [4].

In Asian areas like Chinese Taipei, Mainland China, India, Vietnam and Indonesia motorcycle manufacturing industries are big with a significant economic contribution; most of motorcycles sold in developing countries are made in these countries [1] [2] [3]. Also, China, India, Vietnam and Indonesia are the four largest markets for motorcycle in the world, and the market is growing at the rate of more than 6.5 percent annually [5] [6].

The long list of countries experiencing the rapid growth of Boda-Boda business in their countries is a clear indication that investment in Boda-Boda business is very huge in Africa, particularly in the Sub-Saharan African countries [2] [5] [6] [7]. In Kenya, the registration of motorcycles is increasing every year, similar to Uganda, Tanzania, Togo, Nigeria, and in other Sub-Saharan countries [8] [9].

In six years from 2008 to 2014, Tanzania has registered over 700,000 new motorcycles; the business is attracting investors, youths who seek employment and passengers to avoid long road lines [2]. A Motorcycle taxi may look cheap and quick transport facility in cities and towns of developing countries though it may not be the case if it is well analyzed in all aspects of life. Economically, countries face high demand for imports of motorcycles and its spares; hence, it negatively affects the society, and also, it leads to unfavorable balance of trade and payments, loss of life, noise and environmental pollution as well as the increase of insecurity in cities and towns in the developing countries [2] [4] [8] [9] [10]. Since Motorcycle taxi business has been reported to have negative impact on different spheres of life, one is likely to question on whether Motorcycle taxi (Boda-Boda) business real contributes to sustainable economic, social and environmental development in most developing countries. Some empirical studies suggest significant economic development by rising household and individual income [2] [4] [8] [9] [10]. However, some literature reports both negative and positive impact of Motorcycle taxi business in developing countries [11] 


\section{Problem Statement}

Since the emergency of Motorcycle taxi (Boda-Boda) business in the developing countries, the business has attracted many researchers [2] [4] [8] [9] [10]. The rapid increase of Motorcycle taxis in cities and towns in developing countries is a primary and pushing factor that has made many scholars to pay much attention on the issue. More than 300,000 Motorcycle taxis in Kampala-Uganda by 2015, 832,149 in Tanzania registered Motorcycle taxis were 308,412 by 2010 , 832,149 by 2014 and more than 1 million in both Tanzania and Kenya by 2016 [2] [8] [12] [13] [14]. Boda-Boda have provided employment to youths in both rural and urban areas, more than 1.2 million youths in Kenya, 1.3 million youths in Uganda and 1.1 million youths in Tanzania are employed in this business sector. Also, some empirical studies have reported improvement in standard of life to both Boda-Boda riders and users [2] [4] [8] [12] [13] [14].

Despite the benefit reported, Boda-Boda business is a biting parasite that consumes life and stands as the major cause of lameness in the society, hence raising doubt if it is really beneficial to the society in developing countries [12]. The Boda-Boda (Motorcycle taxis) have caused injuries and death records in developing countries, something that is shocking. In Tanzania, Boda-Boda (Motorcycle taxis) stand as the third cause of deaths after malaria and HIV, causing about 2994 deaths and 820 injuries in the year 2016 [12]. Additionally, the business has added a number of orphans and disables in the society creating an economic burden in the society. The statistics are similar in other countries in East Africa: Nairobi has recorded 391 Boda-Boda caused deaths in 2014 and an average of 3000 Boda-Boda caused deaths countrywide in 2016. In Uganda, Boda-Boda (Motorcycle taxis) stand as the second cause of deaths after HIV; 2000 deaths were registered and 1762 serious accidents in 2011 [15]. The record of deaths, life-long disability and Insecurity in developing countries as a result of the emergency of Motorcycle taxis (Boda-Boda) business raise the question and doubt on whether the business improves people's life economically and socially or it rather causes poverty cycle in the society.

This paper therefore, intends to assess the social and economic consequences of Boda-Boda business in the developing countries in relation to poverty cycle in the communities.

\subsection{Main Objective}

The general objective of this study is to assess the social and economic consequences of Boda-Boda business in the developing countries in relation to poverty cycle in the communities.

\subsection{Specific Objectives}

1) To identify the community attitude on the use of Boda-Boda as a means of transport.

2) To assess the social and economic consequences of Boda-Boda business in the communities. 
3) To relate the social and economic consequences of Boda-Boda business to poverty cycle in the communities.

\section{Methodology}

\subsection{Study Area}

This study was conducted in Mbeya municipality. The preliminary data indicate that the municipality has a large number of Motorcycle taxis (Boda-Boda) and users, as the area is highly congested.

\subsection{Research Design}

This study employed Survey research design, covering of the most important areas in the region gathering information in a broader way, encompassing measurement procedures and involving asking questions to respondents in the covered areas [16]. Surveys offered the opportunity to address a particular research question of long-standing interest to social issues. In particular, Cross-Sectional Surveys was used to collect and assess the frequency within which members of the community perform certain behaviors (using Motorcycle Taxis) or the number of members of the community who hold particular attitudes or beliefs on the studied topic [16] [17].

\subsection{Sampling Procedure}

Purposive sampling technique was adopted, in which the selection of the sample was based on the judgment about some appropriate characteristics required of the sample members, only those officials who were likely to provide data relative to the research findings [17] [18]. It is suggested that this technique allows the researcher to select a sample to serve a specific purpose [18]. The technique was employed in order to meet the objectives of the study, having the sample size of four hundred (400): 200 active users of Motorcycle taxis (Boda-Boda) and 200 long time riders of Motorcycle taxis (Boda-Boda) at least not less than ten years ([17]. the sample were interviewed and filled in the questionnaires.

\subsection{Method of Data Analysis}

Data collected were analysed using Statistical Package for Social Sciences (SPSS) software and Microsoft excel spread sheet was used to provide means, frequency and drawing various charts (Figures 1-3 \& Tables 1-3).

\subsection{Respondents' Analysis}

\section{Demographic Characteristic}

Table 1. Demographic characteristics of Respondents (Motorcycle taxis/Boda-Boda-riders and users).

\begin{tabular}{cccccccc}
\hline $\begin{array}{c}\text { Demographic } \\
\text { Data }\end{array}$ & Description & $\begin{array}{c}\text { No. of Boda-Boda } \\
\text {-riders }\end{array}$ & $\begin{array}{c}\text { Percentage } \\
\text { frequency }\end{array}$ & $\begin{array}{c}\text { No. of Boda-Boda Percentage } \\
\text { - users }\end{array}$ & $\begin{array}{c}\text { Total } \\
\text { frequency }\end{array}$ & Frequency & Percentage \\
\hline Sex & Males & 197 & $98.5 \%$ & 84 & $42 \%$ & 281 & $70.25 \%$ \\
\hline
\end{tabular}


Continued

\begin{tabular}{|c|c|c|c|c|c|c|c|}
\hline & Females & 3 & $0.5 \%$ & 116 & $58 \%$ & 119 & $29.75 \%$ \\
\hline & Total & 200 & $100 \%$ & 200 & $100 \%$ & 400 & $100 \%$ \\
\hline \multirow[t]{5}{*}{ Educational level } & Primary education & 107 & $53.5 \%$ & 68 & $34 \%$ & 175 & $43.75 \%$ \\
\hline & Secondary education & 52 & $26 \%$ & 51 & $25.5 \%$ & 103 & $25.75 \%$ \\
\hline & First Degree & 21 & 10.5 & 32 & $16 \%$ & 53 & $13.25 \%$ \\
\hline & No formal education & 20 & $10 \%$ & 49 & $24.5 \%$ & 69 & $17.25 \%$ \\
\hline & Total & 200 & $100 \%$ & 200 & $100 \%$ & 400 & $100 \%$ \\
\hline \multirow[t]{5}{*}{ Age of the Group } & Below 25 years & 42 & $21 \%$ & 43 & $21.5 \%$ & 85 & $21.25 \%$ \\
\hline & $25-35$ & 120 & $60 \%$ & 56 & $28 \%$ & 176 & $44 \%$ \\
\hline & $36-46$ & 24 & $12 \%$ & 55 & $27.5 \%$ & 79 & $19.75 \%$ \\
\hline & Above 46 & 14 & $7 \%$ & 46 & $23 \%$ & 60 & $15 \%$ \\
\hline & Total & 200 & $100 \%$ & 200 & $100 \%$ & 400 & $100 \%$ \\
\hline
\end{tabular}

Source of Data: Researcher, 2019.

Table 2. Trend of Motorcycle taxis (Boda-Boda) users' involvement in accident and injury sustained.

\begin{tabular}{|c|c|c|c|c|c|c|c|c|c|c|c|c|c|c|c|}
\hline \multirow[t]{2}{*}{$\begin{array}{c}\text { Demographic } \\
\text { Data }\end{array}$} & \multirow[t]{2}{*}{ Description } & \multirow{2}{*}{$\begin{array}{c}\text { No. of } \\
\text { Boda-Boda- } \\
\text { users }\end{array}$} & \multirow{2}{*}{$\begin{array}{l}\text { Percentage } \\
\text { frequency }\end{array}$} & \multicolumn{12}{|c|}{ Motorcycle taxis (Boda-Boda) users accident involvement rate } \\
\hline & & & & 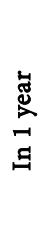 & 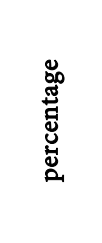 & 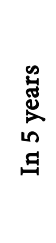 & 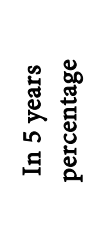 & 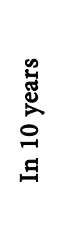 & 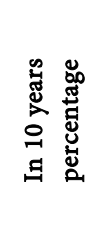 & 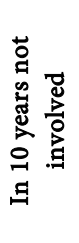 & 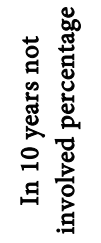 & 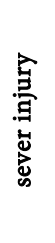 & 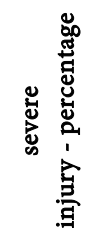 & 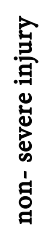 & 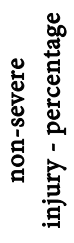 \\
\hline \multirow[t]{3}{*}{ Sex } & Male & 84 & $42 \%$ & 27 & $32.14 \%$ & 52 & $61.90 \%$ & 80 & $95.24 \%$ & 4 & $7.69 \%$ & 32 & $38.10 \%$ & 48 & $57 \%$ \\
\hline & Female & 116 & $58 \%$ & 46 & $39.66 \%$ & 80 & $68.97 \%$ & 102 & $87.93 \%$ & 14 & $17.50 \%$ & 55 & $47.41 \%$ & 47 & $41 \%$ \\
\hline & Total & 200 & $100 \%$ & 73 & $36.50 \%$ & 132 & $66.00 \%$ & 182 & $91.00 \%$ & 18 & $13.64 \%$ & 87 & $43.50 \%$ & 95 & $48 \%$ \\
\hline \multirow[t]{5}{*}{$\begin{array}{l}\text { Educational } \\
\text { level }\end{array}$} & $\begin{array}{l}\text { Primary } \\
\text { education }\end{array}$ & 68 & $34 \%$ & 20 & $29.41 \%$ & 42 & $61.76 \%$ & 65 & $95.59 \%$ & 3 & $7.14 \%$ & 25 & $36.76 \%$ & 40 & $59 \%$ \\
\hline & $\begin{array}{l}\text { Secondary } \\
\text { education }\end{array}$ & 51 & $25.50 \%$ & 19 & $37.25 \%$ & 36 & $70.59 \%$ & 50 & $98.04 \%$ & 1 & $2.78 \%$ & 18 & $35.29 \%$ & 32 & $63 \%$ \\
\hline & First Degree & 32 & $16 \%$ & 15 & $46.88 \%$ & 24 & $75.00 \%$ & 29 & $90.63 \%$ & 3 & $12.50 \%$ & 17 & $53.13 \%$ & 12 & $38 \%$ \\
\hline & $\begin{array}{l}\text { No formal } \\
\text { education }\end{array}$ & 49 & $24.50 \%$ & 19 & $38.78 \%$ & 30 & $61.22 \%$ & 38 & $77.55 \%$ & 11 & $36.67 \%$ & 27 & $55.10 \%$ & 11 & $22 \%$ \\
\hline & Total & 200 & $100 \%$ & 73 & $36.50 \%$ & 132 & $66.00 \%$ & 182 & $91.00 \%$ & 18 & $13.64 \%$ & 87 & $43.50 \%$ & 95 & $48 \%$ \\
\hline \multirow[t]{4}{*}{$\begin{array}{l}\text { Age of the } \\
\text { Group }\end{array}$} & Below 25 years & 43 & $21.50 \%$ & 26 & $60.47 \%$ & 41 & $95.35 \%$ & 42 & $97.67 \%$ & 2 & $4.88 \%$ & 15 & $34.88 \%$ & 27 & $63 \%$ \\
\hline & $25-35$ & 56 & $28 \%$ & 34 & $60.71 \%$ & 52 & $92.86 \%$ & 55 & $98.21 \%$ & 1 & $1.92 \%$ & 32 & $57.14 \%$ & 23 & $41 \%$ \\
\hline & Above 46 & 46 & $23 \%$ & 5 & $10.87 \%$ & 18 & $39.13 \%$ & 33 & $71.74 \%$ & 12 & $66.67 \%$ & 13 & $28.26 \%$ & 20 & $43 \%$ \\
\hline & Total & 200 & $100 \%$ & 73 & $36.50 \%$ & 132 & $66.00 \%$ & 182 & $91.00 \%$ & 18 & $13.64 \%$ & 87 & $43.50 \%$ & 95 & $48 \%$ \\
\hline
\end{tabular}

Source of Data: Researcher, 2019. 
Table 3. Perception of Motorcycle taxis (Boda-Boda) users that Motorcycle Taxis (Boda-Boda) are involved in crime.

\begin{tabular}{|c|c|c|c|c|c|c|c|c|c|}
\hline \multirow[t]{2}{*}{$\begin{array}{l}\text { Demographic } \\
\text { Data }\end{array}$} & \multirow[t]{2}{*}{ Description } & \multirow[t]{2}{*}{$\begin{array}{c}\text { No. of } \\
\text { Boda-Boda- } \\
\text { users }\end{array}$} & \multirow[t]{2}{*}{$\begin{array}{l}\text { Percentage } \\
\text { frequency }\end{array}$} & \multicolumn{6}{|c|}{$\begin{array}{l}\text { Perception of bodaboda users that, } \\
\text { Motorcycle taxis (Boda-Boda) are involved in crime }\end{array}$} \\
\hline & & & & not involved & $\begin{array}{l}\text { not involved } \\
\text { in percentage }\end{array}$ & $\begin{array}{l}\text { Average } \\
\text { involved }\end{array}$ & $\begin{array}{c}\text { Average } \\
\text { involved in } \\
\text { percentage }\end{array}$ & $\begin{array}{l}\text { highly } \\
\text { involved }\end{array}$ & $\begin{array}{c}\text { highly } \\
\text { involved in } \\
\text { percentage }\end{array}$ \\
\hline \multirow[t]{3}{*}{ Sex } & Male & 84 & $42 \%$ & 0 & $0.00 \%$ & 34 & $40.48 \%$ & 50 & $59.52 \%$ \\
\hline & Female & 116 & $58 \%$ & 1 & $0.86 \%$ & 21 & $18.10 \%$ & 94 & $81.03 \%$ \\
\hline & Total & 200 & $100 \%$ & 1 & $0.50 \%$ & 55 & $27.50 \%$ & 144 & $72.00 \%$ \\
\hline \multirow[t]{5}{*}{$\begin{array}{l}\text { Educational } \\
\text { level }\end{array}$} & $\begin{array}{l}\text { Primary } \\
\text { education }\end{array}$ & 68 & $34 \%$ & 1 & $1.47 \%$ & 21 & $30.88 \%$ & 46 & $67.65 \%$ \\
\hline & $\begin{array}{l}\text { Secondary } \\
\text { education }\end{array}$ & 51 & $25.50 \%$ & 0 & $0.00 \%$ & 12 & $23.53 \%$ & 39 & $76.47 \%$ \\
\hline & First Degree & 32 & $16 \%$ & 0 & $0.00 \%$ & 4 & $12.50 \%$ & 28 & $87.50 \%$ \\
\hline & $\begin{array}{l}\text { No formal } \\
\text { education }\end{array}$ & 49 & $24.50 \%$ & 0 & $0.00 \%$ & 18 & $36.73 \%$ & 31 & $63.27 \%$ \\
\hline & Total & 200 & $100 \%$ & 1 & $0.50 \%$ & 55 & $27.50 \%$ & 144 & $72.00 \%$ \\
\hline \multirow[t]{5}{*}{$\begin{array}{l}\text { Age of the } \\
\text { Group }\end{array}$} & $\begin{array}{c}\text { Below } 25 \\
\text { years }\end{array}$ & 43 & $21.50 \%$ & 0 & $0.00 \%$ & 27 & $62.79 \%$ & 16 & $37.21 \%$ \\
\hline & $25-35$ & 56 & $28 \%$ & 1 & $1.79 \%$ & 22 & $39.29 \%$ & 33 & $58.93 \%$ \\
\hline & $36-46$ & 55 & $27.50 \%$ & 0 & $0.00 \%$ & 4 & $7.27 \%$ & 51 & $92.73 \%$ \\
\hline & Above 46 & 46 & $23 \%$ & 0 & $0.00 \%$ & 2 & $4.35 \%$ & 44 & $95.65 \%$ \\
\hline & Total & 200 & $100 \%$ & 1 & $0.50 \%$ & 55 & $27.50 \%$ & 144 & $72.00 \%$ \\
\hline
\end{tabular}

Source of Data: Researcher, 2019.

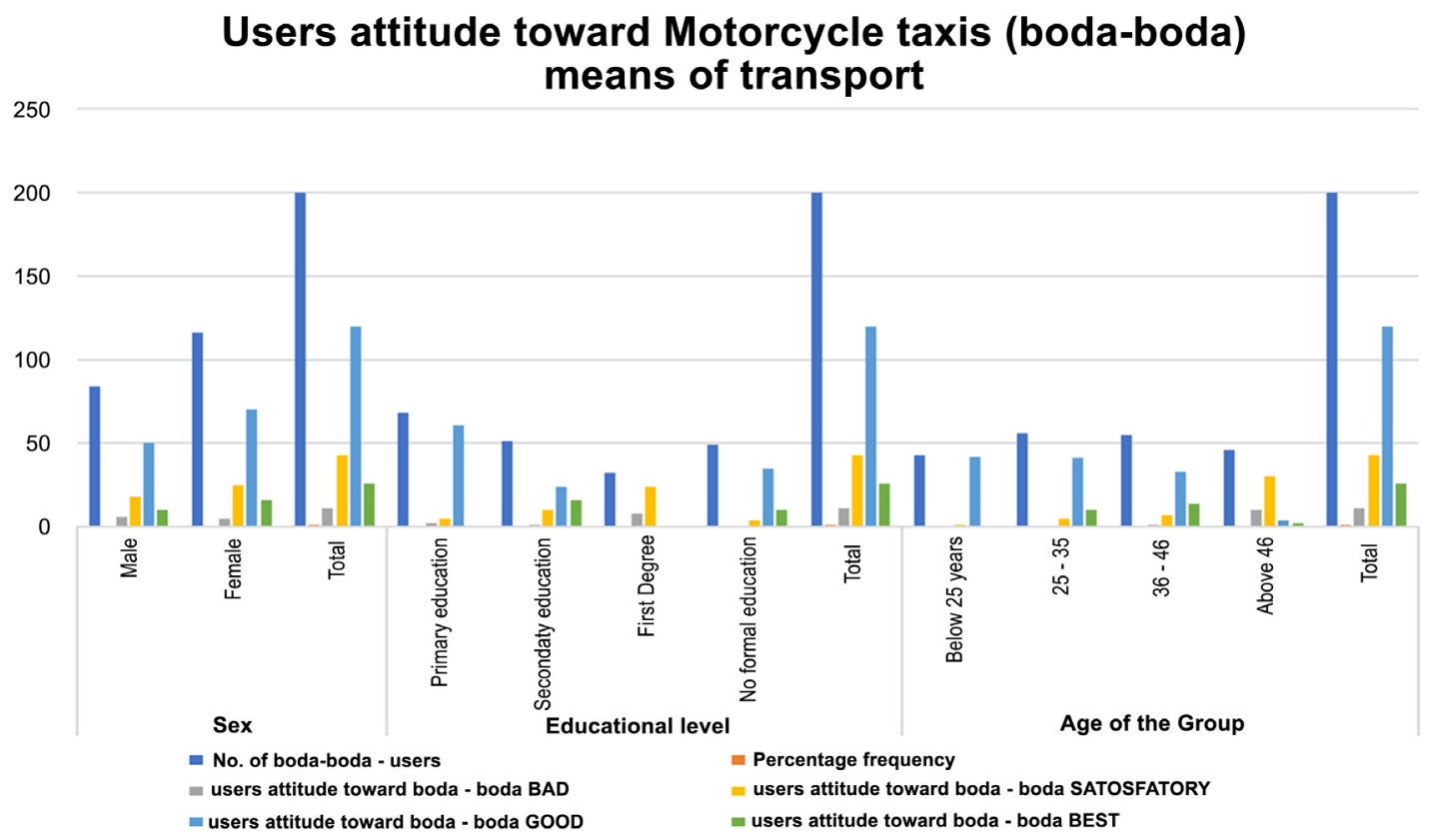

Figure 1. Motorcycle taxis (Boda-Boda) users' attitude on the use of Motorcycle taxis (Boda-Boda) as a means of transport. Source of Data: Researcher, 2019. 


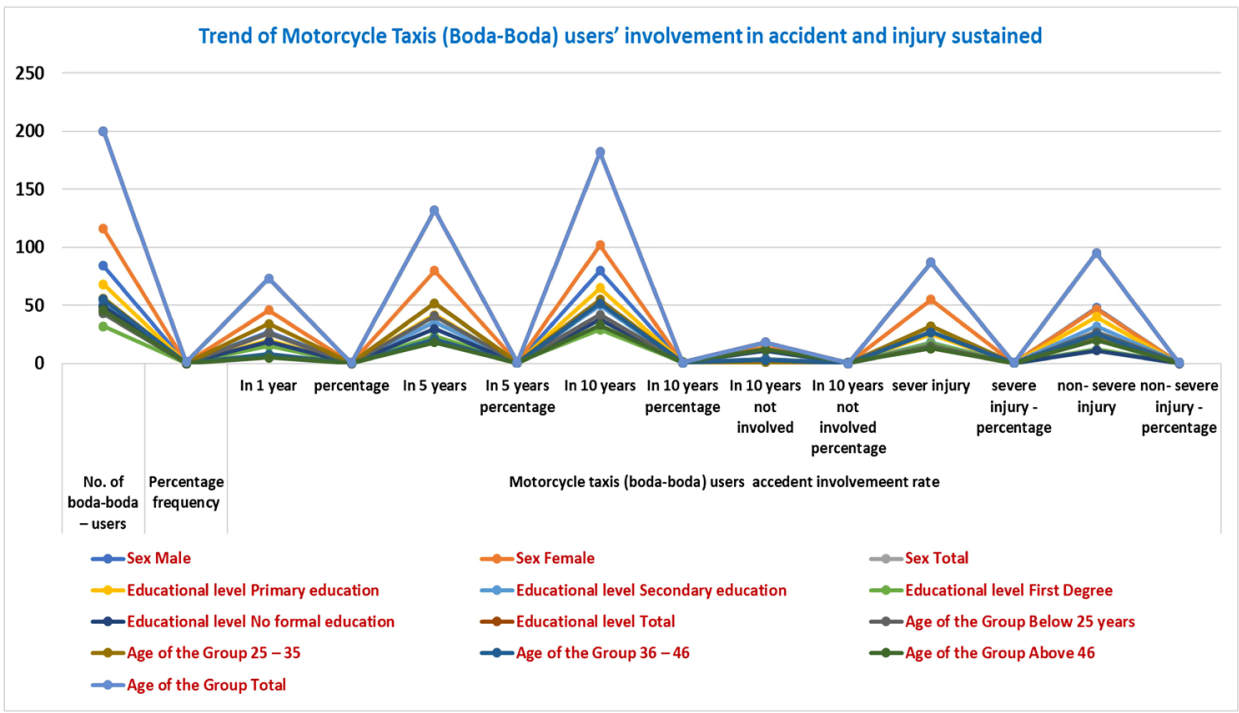

Figure 2. Trend of Motorcycle taxis (Boda-Boda) users' involvement in accident and injury sustained. Source of Data: Researcher, 2019.

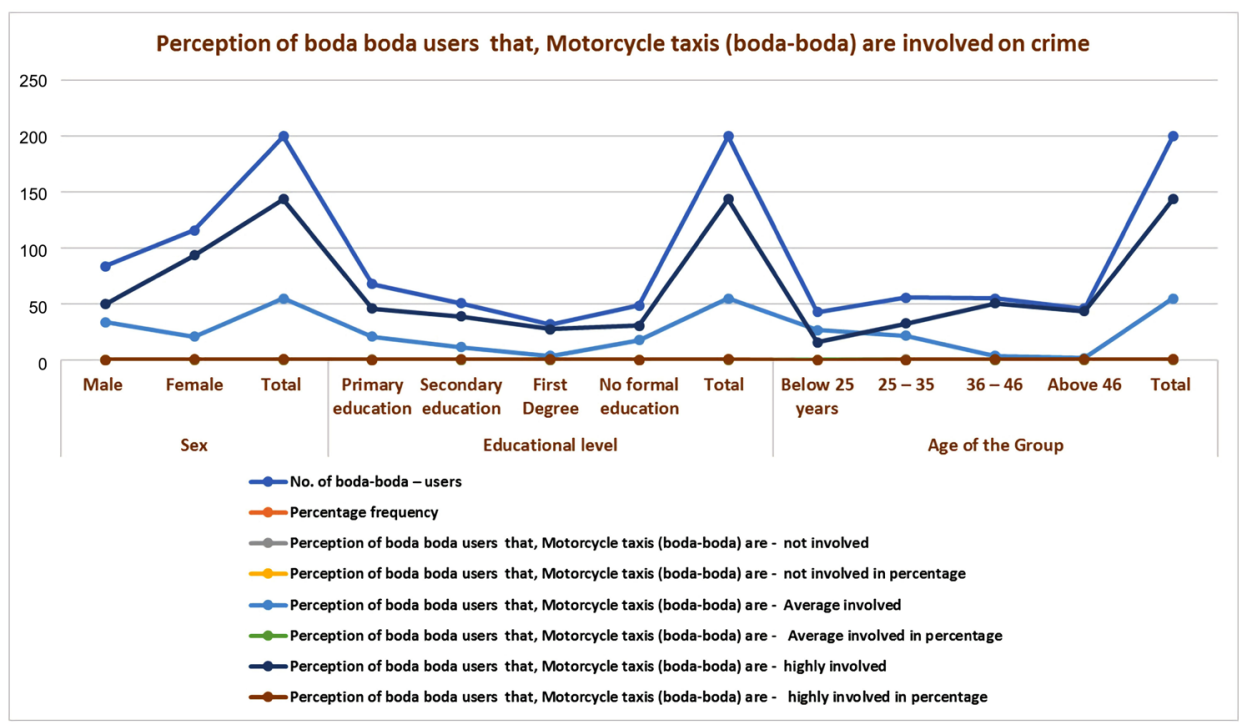

Figure 3. Perception of Motorcycle taxis (Boda-Boda) users that, Motorcycle taxis (Boda-Boda) are involved in crime. Source of Data: Researcher, 2019.

\section{Data Presentation, Analysis and Discussion}

In this section, the researcher presents the research findings, data analysis and discussion as they have been obtained from various sources.

Motorcycle taxis (Boda-Boda) users have good attitude toward Motorcycle taxis (Boda-Boda) particularly young users, which constitutes about $60 \%$, as they consider Motorcycle taxis (Boda-Boda) to be good means of transport. This means of transport is more popular among young age and female users. Age wise, $97.67 \%$ of users are below 25 years of age and $73.21 \%$ of users are between 25 and 35 years of age, they consider Motorcycle taxis (Boda-Boda) to be a good means of transport. Also, it is popular among highly educated people who use it 
in order to escape long queue and lack of other means of transport.

Social, and economic consequences of Boda-Boda business in the communities

Trends of Motorcycle taxis (Boda-Boda) users' involvement in accident are shocking, almost all Motorcycle taxis (Boda-Boda) users in the past five years or above were involved in accident, some with severe injuries. In the past ten years, 91\% of the sample Motorcycle taxis (Boda-Boda) users were involved in accident, the reflection that, in long-run the whole population of Motorcycle taxis (Boda-Boda) users are involved or will be involved in accident. Also, in the past ten years, $43 \%$ of the sample of Motorcycle taxis (Boda-Boda) users have sustained severe injuries whereby $88 \%$ are aged below 46 years. This provides an alert that the business is totally destroying the working force of the region and the nation at large. In relation to poverty cycle in the community, the data presented by Satar R, Mohammad and A, Behzad K, in 2014 provide that, the annual costs of injuries costs by low-income earners and middle-income earners community are valued to be 65 billion US dollars in the country, exceeding the amount received in development assistance in the country [19] and Motorcycle taxis (Boda-Boda) crash statistics are more than doubling every year causing deaths, injuries and encroaching the country work force, income and the whole economy at large.

The number of disabled and orphans is also increasing as the result of these Motorcycle taxis (Boda-Boda) related crashes, creating the burden of dependents in the society. It is predicted that in the year 2020, Africa will be ranked $3^{\text {rd }}$ on cause of road accidents and life adjustment, claiming life, income and creating burden to government [20] [21] [22]. Death toll was more than 800 people annually in the country (http://www.xinhuanet.com).

The reflection does not differ from those reported in other parts of the country. In Dodoma, 38,237 accidents involved motorcycles from 2008 to September, 2018 [23]. Also, deaths amounted to 8237 from 2008 to September, 2018 involved motorcycle accidents and 37,521 injuries, meaning that an average of 823 people died every year in the country [23]

Most of Motorcycle taxis (Boda-Boda) users not only are aware of crimes involving Motorcycle axis (Boda-Boda) in community but also believe Motorcycle taxis (Boda-Boda) are involved in crime scenes in community. $81 \%$ of Motorcycle taxis (Boda-Boda) users perceive Motorcycle taxis (Boda-Boda) to be involved in crimes in the community.

\section{Conclusion and Recommendation}

Motorcycle taxis (Boda-Boda) users in ten years have more than $90 \%$ chances to sustain injuries or lose life. Though users and riders have positive attitude on Motorcycle taxis (Boda-Boda), more than $80 \%$ of them are aware of the risks associated with them. Primary data with the support of secondary data indicate that the Motorcycle taxis (Boda-Boda) business has negative impact in commu- 
nity; thus, it is difficult to say that the business contributes to economic growth, instead it fuels poverty cycle, from unemployment to purely disabled dependents or from jobless fathers or mothers to orphans and dependents. The government should intervene in the Motorcycle taxis (Boda-Boda) business which erodes the country's manpower, resources and the economy at large.

\section{Conflicts of Interest}

The authors declare no conflicts of interest regarding the publication of this paper.

\section{References}

[1] Mutiso, W. and Behrens, R. (2011) "BodaBoda" Bicycle Taxis and Their Role in Urban Transport Systems: Case Studies of Kisumu and Nakura, Kenya. http://repository.up.ac.za/handle/2263/17308

[2] Bishop, T. and Amos, P. (2015) Opportunities to Improve Road Safety through "Boda-Boda" Associations in Tanzania.

[3] Kumar, A. and Diou, C. (2010) The Dakar Bus Renewal Scheme: Before and After. World Bank, Washington DC.

[4] Olvera, L.D., Plat, D., Pochet, P. and Maïdadi, S. (2012) Motorbike Taxis in the “Transport Crisis” of West and Central African Cities. EchoGéo, 20, 1-18. https://doi.org/10.4000/echogeo.13080

[5] De Vreyer, P. and Roubaud, F. (2013) Urban Labor Markets in Sub-Saharan Africa. World Bank Publications, Washington DC. https://doi.org/10.1596/978-0-8213-9781-7

[6] Lawrence, N.N. (2012) The Socio-Cultural Impact of the Introduction of Motorbike Taxis in the Rural Community of Tombel, South West Region, Cameroon. Master Thesis, Université de Yaoundé, Yaoundé.

[7] Kitara, D.L. (2011) BodaBoda Injuries in Gulu Regional Hospital, Northern Uganda. https://www.researchgate.net/publication/279424871

[8] Howe, J. (2001) BodaBoda-Uganda's Rural and Urban Low-Capacity Transport Services. Unpublished DFID Funded Research Project. Makerere University, Kampala.

[9] Mahlstein, M. (2009) Shaping and Being Shaped: The Regulation of Commercial Motorcycle Operation and Social Change in Calabar, Nigeria. MA Thesis, University of Basel, Basel.

[10] Rizzo, M. (2011) The Struggles of Informal Transport Workers in Tanzania: Debunking the Myth of Micro Solutions. Development Viewpoint No. 68, 2. http://www.soas.ac.uk/cdpr/publications/dv/dv68.html

[11] Goodfellow, T. and Titeca, K. (2012) Presidential Intervention and the Changing "Politics of Survival" in Kampala's Informal Economy. Cities, 29, 264-270. https://doi.org/10.1016/j.cities.2012.02.004

[12] Leonard, M. (2016) 2016 Mwaka Wa Ajali Mabasi, Bodaboda Zaongoza. http://www.tanzaniatoday.co.tz/news/2016

[13] https://www.bbc.com/swahili/habari/2016/03/160302_motorcycle_tz

[14] http://bodaassociationofk.wixsite.com/bodaboda

[15] Francis, M. (2016) NTSA Blames Boda-Boda Accidents on Impunity Avail. 
https://www.nation.co.ke/news/ntsa-blames-boda-boda-deaths-on-impunity/1056-3 831760-soic1fz/index.html

[16] Dudovskiy, J. (2018) The Ultimate Guide to Writing a Dissertation in Business Studies: A Step-by-Step Assistance.

https://research-methodology.net/about-us/ebook

[17] Kothari, C.R. (2009) Research Methodology Methods and Techniques. 2nd Edition, New Age International (P) Ltd., New Delhi.

[18] Zikmund, W.G. (1988) Business Research Methods. 3rd Edition, The Dryden Press, New York, 85-99.

[19] Satar, R., Mohammad, A., Behzad, K. and Ali, S. (2014) Consequences and Economic Burden of Road Traffic Crashes in Iran. Journal of Injury and Violence Research, 6, 57-63. https://doi.org/10.5249/jivr.v6i2.191

[20] Mock, C.N., Abatanga, F. and Koepsell, T.D. (1999) Incidence and Outcome of Injury in Ghana: A Community Based Survey. The Bulletin of the World Health Organization, 77, 955-964.

[21] Krug, E.G., Sharma, G.K. and Lozano, R. (2000) The Global Burden of Injuries. American Journal of Public Health, 90, 523-526. https://doi.org/10.2105/AJPH.90.4.523

[22] Smith, G.S. and Barss, P. (1991) Unintentional Injuries in Developing Countries; the Epidemiology of a Neglected Problem. Epidemiologic Reviews, 13, 228-266. https://doi.org/10.1093/oxfordjournals.epirev.a036070

[23] Xinhua (2018) Motorcycle Accidents in Tanzania Kill 800 People Annually: Minister. http://www.xinhuanet.com/english/africa/2018-11/07/c_137589980.htm 